\title{
Effect of Irrigation Management and Water Conservation Practices on Growth and Yields in Yellow Sarson (Brassica rapa L.) in Uttarakhand Region
}

\author{
Samar Pal Singh ${ }^{1 *}$, B.S. Mahapatra ${ }^{2}$ and Vimal Raj Yadav ${ }^{3}$ \\ ${ }^{1}$ Agronomy, KVK, New Delhi, India \\ ${ }^{2}$ Department of Agronomy, G.B.P.U.A\&T, Pantnagar -263 145 (Uttarakhand), India \\ ${ }^{3}$ Agronomy, KVK, Jhansi (U.P), India \\ *Corresponding author
}

A B S T R A C T

\section{Keywords}

Irrigation levels, Dry matter accumulation (Stem and leaves) and Yield

Article Info

Accepted:

04 January 2019

Available Online:

10 February 2019
Field experiments were conducted for two consecutive rabi seasons during 2014-15 and 2015-16 at Norman E. Borlaug Crop Research Centre of G.B. Pant University of Agriculture and Technology, Pantnagar to evaluate growth and yield parameters of yellow sarson (Brassica rapa L.) affected by different irrigation levels, planting methods and mulching. Significantly higher numbers of leaves per plant and dry matter accumulation in leaves and stem were reported at $1.2 \mathrm{IW} / \mathrm{CPE}$ ratio over 0.6 and 0.3 IW/CPE ratio in both the years of study. Seed yield of yellow sarson increased significantly up to $0.9 \mathrm{IW} / \mathrm{CPE}$ ratio as compared to remained irrigation levels. In both the years, yellow sarson planted on raised bed produced 11.5 and 7.1 per cent higher seed yield with higher number of leaves over flat bed planting method, respectively. Application of rice straw mulch recorded 11.7 and 12.3 per cent significantly higher seed yield than no mulch, respectively.

\section{Introduction}

Oilseeds plays a vital role in Indian economy, account second largest agricultural commodities after cereals sharing 13 per cent of the country's gross cropped area, nearly 5 per cent of gross national product and 10 per cent of the value of all agricultural products. Rapeseed-mustard cultivation in 6.42 million hectare area and the production is 6.33 million tonnes in 2017-18. However, its average productivity is $12.50 \mathrm{~kg} / \mathrm{ha}$ (GOI,
Ministry of Agriculture, 2017). The requirement of vegetable oils and fats will be much higher in coming years in view of ever increasing population. India would need 58 million tons of oilseeds by 2020 for maintaining minimum edible oil requirement. To produce an additional quantity of oilseeds, the only option is to enhance productivity under the limited land resource condition. Generally, rapeseed- mustard sown under rainfed conditions in residual soil moisture in marginal and sub-marginal land in rabi 
season. Optimum moisture need to maintain in root zone, to meet the crop water requirements for higher production and productivity. It can be achieved best through adopting the improved irrigation scheduling and conservation practices. Water requirement of yellow sarson is not so high but to exploit full potential of this crop, it is essential to provide sufficient water balance at least at the time of the critical stages of the crop. The raised bed planting method can be viable practice in reducing the water losses and utilizing conserved soil moisture. Mulches prevent soil from blowing and being washed away reduces evaporation, increase infiltration, keeps down weeds, improves soil structure and eventually increases crop yields. Studies on mulching carried out in India under rainfed agriculture have concentrated on the measurement of crop responses rather than on the manner in which crop responses are influenced.

\section{Materials and Methods}

The field experiments were carried out during rabi season of 2014-15 and 2015-16 at Water Management (Agronomy) section at Norman E. Borlaug Crop Research Centre of G.B. Pant University of Agriculture and Technology, Pantnagar, District Udham Singh Nagar (Uttarakhand). The soil of experimental field was sandy loam in texture and had $238.3 \mathrm{~kg} / \mathrm{ha} \mathrm{N}, 15.71 \mathrm{~kg}$ available $\mathrm{P}$ $\mathrm{kg} / \mathrm{ha}, 185.6 \mathrm{~kg} / \mathrm{ha} \mathrm{K}, 0.87 \%$ organic carbon with $7.4 \mathrm{pH}$ of soil (1: 2.5 soil: water). The experiments were laid out in Split plot design (SPD) with three replications and 16 treatment combinations. The treatments consisted of 4 irrigation levels (0.3, 0.6, 0.9 and 1.2 IW/CPE ratios), 2 planting methods (flat bed and raised bed) and 2 mulching treatments (mulch and no mulch). All the plots were uniformly fertilized with 120:60:30 $\mathrm{kg} / \mathrm{ha}\left(\mathrm{N}: \mathrm{P}_{2} \mathrm{O}_{5}: \mathrm{K}_{2} \mathrm{O}\right.$, respectively). For dry matter plants were sun-dried for 48 hours.
After sun drying, these plants were dried in the oven at $65 \pm 5^{\circ} \mathrm{C}$ temperature for $48-72$ hours or till the samples attained a constant weight, and weighed. The dry matter was expressed in $\mathrm{g} / \mathrm{plant}$. Total number of leaves was counted by selecting four plants from the tagged plants of the observational rows of each plot. Yellow sarson variety "Pant Pili Sarson -1" was sown at $30 \mathrm{~cm} \times 10 \mathrm{~cm}$ spacing. Rice straw mulch (@ 5 tones/ha) was applied according to the treatment after 25 DAS of crop. From the individual plot, the net plot area was harvested separately and produce was sun dried. After sundried, the crop was threshed and produce was cleaned. The weight was recorded in $\mathrm{kg}$ per plot and finally converted into $\mathrm{q} / \mathrm{ha}$ by using conversion factor.

\section{Results and Discussion}

\section{Number of leaves and dry matter accumulation}

In 2014-15, irrigation at $1.2 \mathrm{IW} / \mathrm{CPE}$ ratio reported significantly higher number of large leaves and smaller leaves as compared to remaining irrigation levels while at par with $0.9 \mathrm{IW} / \mathrm{CPE}$ ratio in case of smaller leaves at 60 DAS. The minimum no. of large and small leaves was recorded under no irrigation at 0.3 IW/CPE ratio. In 2015-16, higher numbers of large and small leaves also recorded at 1.2 IW/CPE ratio which was significantly superior over remaining irrigation levels but at par with $0.9 \mathrm{IW} / \mathrm{CPE}$ ratio in case of large leaves at 60 DAS. No significant difference in small and large leaves was found at 0.6 IW/CPE ratio and $0.3 \mathrm{IW} / \mathrm{CPE}$ ratio. Similar findings were also illustrated by Dudwal et al., (2013) also found more leaves per plant in 3 irrigation levels than 1, 2 and control. At 60 DAS, irrigation levels significantly influenced the dry matter accumulation in leaves and stem of crop in both the years. In 2014-15, dry matter accumulation in leaves and stem 
increased significantly at $1.2 \mathrm{IW} / \mathrm{CPE}$ ratio as compared to remaining irrigation levels. Further, 0.9 IW/CPE ratio was recorded significantly higher dry matter accumulation in leaves and stem of crop over 0.6 IW/CPE and 0.3 IW/CPE ratio. In 2015-16, significantly higher dry matter in leaves and stem was recorded at $1.2 \mathrm{IW} / \mathrm{CPE}$ ratio than remaining irrigation levels followed by 0.9 IW/CPE ratio. Dry matter in leaves and stem did not showed significant difference at 0.6 IW/CPE ratio and 0.3 IW/CPE ratio.

Table.1 Effect of irrigation levels, planting methods and mulching on number of leaves per plant, dry matter accumulation (gm) per plant and seed yield of crop at different days after sowing in 2014-15 and 2015-16

\begin{tabular}{|c|c|c|c|c|c|c|c|c|c|c|}
\hline \multirow[t]{3}{*}{ Treatment } & \multicolumn{4}{|c|}{ Number of Leaves per plant } & \multicolumn{4}{|c|}{$\begin{array}{l}\text { Total dry matter (gm) per } \\
\text { plant }\end{array}$} & \multicolumn{2}{|c|}{$\begin{array}{c}\text { Seed yield } \\
(\mathrm{q} / \mathrm{ha})\end{array}$} \\
\hline & \multicolumn{2}{|c|}{ 2014-15 } & \multicolumn{2}{|c|}{$2015-16$} & \multicolumn{2}{|c|}{ 2014-15 } & \multicolumn{2}{|c|}{ 2015-16 } & \multirow{2}{*}{$\begin{array}{c}2014- \\
15 \\
\text { Seed } \\
\text { yield } \\
\text { (q/ha) }\end{array}$} & \multirow{2}{*}{$\begin{array}{c}2015- \\
16 \\
\text { Seed } \\
\text { yield } \\
\text { (q/ha) }\end{array}$} \\
\hline & $\begin{array}{l}\text { Large } \\
\text { leaves }\end{array}$ & $\begin{array}{l}\text { Smaller } \\
\text { leaves }\end{array}$ & $\begin{array}{l}\text { Large } \\
\text { leaves }\end{array}$ & $\begin{array}{l}\text { Smaller } \\
\text { leaves }\end{array}$ & Leaves & Stem & Leaves & Stem & & \\
\hline \multicolumn{11}{|c|}{ Irrigation level (IW/CPE ratio) } \\
\hline $\begin{array}{c}\text { 0.3 } \\
\text { IW/CPE }\end{array}$ & 10.8 & 34.5 & 11.8 & 31.2 & 3.88 & 7.14 & 4.38 & 8.25 & 9.9 & 9.3 \\
\hline $\begin{array}{c}\text { 0.6 } \\
\text { IW/CPE }\end{array}$ & 10.9 & 34.3 & 12.2 & 33.5 & 3.93 & 7.48 & 4.46 & 8.55 & 10.7 & 12.2 \\
\hline $\begin{array}{c}\text { 0.9 } \\
\text { IW/CPE }\end{array}$ & 15.0 & 42.3 & 18.7 & 47.4 & 4.93 & 10.13 & 5.52 & 10.85 & 13.0 & 14.8 \\
\hline $\begin{array}{c}1.2 \\
\text { IW/CPE }\end{array}$ & 16.3 & 45.8 & 19.1 & 53.2 & 5.66 & 11.29 & 6.44 & 12.27 & 14.1 & 16.0 \\
\hline SEm \pm & 0.4 & 1.2 & 0.5 & 1.5 & 0.04 & 0.22 & 0.15 & 0.15 & 0.36 & 0.14 \\
\hline $\begin{array}{c}\text { LSD } \\
(\mathbf{P}=\mathbf{0 . 0 5})\end{array}$ & 1.3 & 4.3 & 1.8 & 5.3 & 0.14 & 0.76 & 0.52 & 0.51 & 1.26 & 0.48 \\
\hline \multicolumn{11}{|c|}{ Planting method } \\
\hline Flat bed & 12.3 & 37.0 & 13.5 & 39.8 & 4.31 & 8.38 & 4.92 & 9.50 & 11.3 & 12.6 \\
\hline $\begin{array}{c}\text { Raised } \\
\text { bed }\end{array}$ & 14.1 & 41.5 & 17.4 & 42.8 & 4.89 & 9.63 & 5.48 & 10.45 & 12.6 & 13.5 \\
\hline SEm \pm & 0.3 & 1.1 & 0.5 & 1.0 & 0.05 & 0.14 & 0.13 & 0.19 & 0.20 & 0.18 \\
\hline $\begin{array}{c}\text { LSD } \\
(\mathbf{P}=\mathbf{0 . 0 5})\end{array}$ & 1.0 & 3.1 & 1.4 & NS & 0.16 & 0.40 & 0.36 & 0.56 & 0.59 & 0.51 \\
\hline \multicolumn{11}{|l|}{ Mulching } \\
\hline No Mulch & 12.4 & 37.1 & 14.5 & 37.1 & 4.15 & 8.33 & 4.60 & 8.69 & 11.3 & 12.3 \\
\hline Mulch & 14.1 & 41.4 & 16.4 & 45.5 & 5.05 & 9.68 & 5.80 & 11.27 & 12.6 & 13.9 \\
\hline SEm \pm & 0.3 & 1.1 & 0.5 & 1.0 & 0.05 & 0.14 & 0.13 & 0.19 & 0.20 & 0.18 \\
\hline $\begin{array}{c}\text { LSD } \\
(\mathbf{P}=\mathbf{0 . 0 5})\end{array}$ & 1.0 & 3.1 & 1.4 & 3.0 & 0.16 & 0.40 & 0.36 & 0.56 & 0.59 & 0.51 \\
\hline
\end{tabular}


During both the years, number of large and small leaves influenced by planting methods at 60 DAS. In both the years, raised bed planting method reported more number of large and small leaves than flat bed at 60 DAS. In 2014-15, raised bed planting registered and 14.6 and 12.3 per cent more large and small leaves over flat bed planting method at 60 DAS, respectively. In 2015-16, yellow sarson planting on raised bed produced 28.7 and 7.4 per cent more large and small leaves than flatbed planting method at 60 DAS, respectively. Buttar et al., (2006) noticed $9 \%$ higher leaves under bed planting than conventional method. In 2014-15, raised bed planting registered 13.5 and 15 per cent more dry matter accumulation in leaves and stem over flat bed planting method at 60 DAS, respectively. In 2015-16, yellow sarson sowing on raised bed reported 11.4 and 10 per cent more dry matter accumulation in leaves and stem over flatbed planting method at 60 DAS, respectively. In 2014-15, application of mulch reported 14.3 and 11.6 per cent more large and small leaves over no mulch at 60 DAS, respectively. In 2015-16, 13 and 23 per cent higher large and small leaves ware recorded with mulch as compared to number mulch at $60 \mathrm{DAS}$, respectively. These results are in close conformity with the findings of Tetrawal et al., (2013). Mulching significantly influenced dry matter accumulation in leaves and stem of yellow sarson at 60 DAS during both years. In 2014 15, application of mulch reported 21.7 and 16.2 per cent higher dry matter accumulation in leaves and stem as compared to no mulch at 60 DAS, respectively. In 2015-16, 26.1 and 29.7 percent more dry matter accumulation in leaves and stem was recorded with mulch over no mulch at 60 DAS, respectively. The seed yield differed significantly due to irrigation levels in both the years (Table- 1). In 2014-15, seed yield increased significantly at $1.2 \mathrm{IW} / \mathrm{CPE}$ ratio over $0.6 \mathrm{IW} / \mathrm{CPE}$ ratio and $0.3 \mathrm{IW} / \mathrm{CPE}$ ratio while at par with 0.9
IW/CPE ratio. The seed yield did not exhibit significant difference between 0.6 IW/CPE ratio and 0.3 IW/CPE ratio. In 2015-16, seed yield increased significantly at $1.2 \mathrm{IW} / \mathrm{CPE}$ ratio as compared to $0.9 \mathrm{IW} / \mathrm{CPE}$ ratio, 0.6 IW/CPE ratio and $0.3 \mathrm{IW} / \mathrm{CPE}$ ratio. Further, $0.9 \mathrm{IW} / \mathrm{CPE}$ ratio increased the seed yield significantly over $0.6 \mathrm{IW} / \mathrm{CPE}$ and 0.3 IW/CPE ratio. Significant improvement in seed yield might be a consequence of the increased number of siliquae per plant, number of seeds per siliqua, length of siliqua and the 1000-seed weight. Similar findings were also illustrated by Yadav et al., (2010) and Ray et al., (2015) reported significantly higher seed yield with increase in irrigation frequency. During both the years, the seed yield affected significantly by the planting methods. In 2014-15, raised bed planting method registered 11.5 per cent more seed yield over flat bed planting method. In 201516 , sarson sowing on raised bed produced 7.1 per cent higher seed yield than flatbed planting method. Similar effects of planting methods have been reported by Buttar et al., (2006) and Kuotsua et al., (2014). Mulching had significant influenced on seed yield in both years. In 2014-15, application of mulch recorded 11.7 per cent more seed yield than no mulch. In 2015-16, 12.3 percent higher seed yield was recorded with mulch as compared to no mulch. The highest seed yield obtained under paddy straw mulch in this study conformed to earlier report by Sarangi et al., (2010) and Sharma et al., (2014) also reported that the seed yield of mustard was higher with the application of paddy straw mulch.

It was concluded that in good rainfall season, yellow sarson irrigated at $0.9 \mathrm{IW} / \mathrm{CPE}$ ratio and under no rainfall, irrigated at $1.2 \mathrm{IW} /$ CPE ratio with mulch under raised bed planting method in sandy loam soil is beneficial and effective for achieving economic yield advantage of yellow sarson. 


\section{References}

Buttar, G.S., Thind, H.S. and Aujla, M.S. 2006. Methods of planting and irrigation at various levels of nitrogen affect the seed yield and water use efficiency in transplanted oilseed rape (Brassica napus L.). Agriculture Water Management 85: 253-260.

Dudwal, B. L., Yadav, S. K., Rakesh, K., Meena, R. L. and Hassim, M. 2013. Performance and production potential of Mustard (Brassica juncea L.) to different levels of irrigation in the central plain zone of Uttar Pradesh, India. Agric. Sci. Digest. 33(1): 33-37.

GOI (Government of India) (2017). Agricultural Statistics at a Glance. Agricultural Statistics Division, Department of Agriculture and Cooperation and Farmers Welfare, Ministry of Agriculture, GOI, New Delhi.

Kuotsu, K., Munda, G. C., Das, A. and Verma, B. C. 2014. Soil health as affected by altered land configuration and conservation tillage in a groundnut (Arachis hypogaea)-toria (Brassica campestris var. toria) cropping system. Indian J. Agric. Sci. 84(2): 241-247.

Ray, K., Sengupta, K., Pal1, A. K. and
Banerjee, H. 2015. Effects of sulphur fertilization on yield, $S$ uptake and quality of Indian mustard under varied irrigation regimes. Plant Soil Environ, 61(1): 6-10.

Sarangi, S. K., Saikia, U. S. and Lama, T. D. 2010. Effect of rice (Oryza sativa) straw mulching on the performance of rapeseed (Brassica campestris) varieties in rice-rapeseed cropping system. Indian J. Agric. Sci., 80(7): 603-605.

Sharma, B. K., Yadav, K. S., Gurjar, N. S. and Sharma, J. 2014. Productivity and profit ability of rainfed mustard (Brassica juncea L.) in relation to sowing time and moisture conservation practices in alluvial soil of Madhya Pradesh. Prog. Agric. 14(2): 295-299.

Tetarwal, J.P., Ram, B., Meena, D.S. and Tomar, S.S. 2013. Effect of moisture conservation and sulphur sources on productivity and water use efficiency of Indian mustard (Brassica juncea) under rainfed conditions Indian Journal of Agronomy 58(2): 231-236.

Yadav, R.P., Tripathi, M.L. and Trivedi, S.K. 2010. Yield and quality of Indian mustard (Brassica juncea) as influenced by irrigation and nutrient levels. Indian Journal of Agronomy 55 (1): 56-59.

\section{How to cite this article:}

Samar Pal Singh, B.S. Mahapatra and Vimal Raj Yadav. 2019. Effect of Irrigation Management and Water Conservation Practices on Growth and Yields in Yellow Sarson (Brassica rapa L.) in Uttarakhand Region. Int.J.Curr.Microbiol.App.Sci. 8(02): 151-155.

doi: https://doi.org/10.20546/ijcmas.2019.802.018 